\title{
Seminal plasma androgen-binding protein activity in turkeys with normal white or abnormal yellow semen
}

\author{
R. A. Hess*, G. P. Birrenkott, Jr and R. J. Thurston \\ Department of Poultry Science, Clemson University, Clemson, South Carolina 29631, U.S.A.
}

\begin{abstract}
Summary. Dihydrotestosterone (DHT) binding activity of normal white and abnormal yellow turkey semen was quantitated by disc-gel electrophoresis in the presence of $\left[{ }^{3} \mathrm{H}\right] \mathrm{DHT}$. White seminal plasma had three peaks of activity $\left(R_{\mathrm{f}}=0.3,0.5\right.$ and 0.8$)$. Yellow seminal plasma had a greater protein concentration and $\left[{ }^{3} \mathrm{H}\right] \mathrm{DHT}$ binding activity averaging $32.5 \pm 7.93 \mathrm{pmol} \mathrm{DHT} / \mathrm{ml}$ compared with $1.45 \pm 0.3 \mathrm{pmol} \mathrm{DHT} / \mathrm{ml}$ for white seminal plasma. The majority of [ $\left.{ }^{3} \mathrm{H}\right] \mathrm{DHT}$ binding was localized at $R_{\mathrm{f}}=0.5$ for the yellow seminal plasma. When labelled samples were separated by electrophoresis on unlabelled gels, the only peak of activity was at $R_{\mathrm{f}}=0 \cdot 5$. Blood serum contained 3 peaks of activity $\left(R_{\mathrm{f}}=0 \cdot 4,0.5\right.$, and 0.8$)$. We conclude that a seminal plasma androgen-binding protein is present in the domestic turkey, and in males with yellow semen syndrome androgen-binding activity is increased.
\end{abstract}

\section{Introduction}

Androgen-binding protein (ABP) is a specific androgen-transporting protein (Tindall \& Means, 1980) which has been isolated from the male reproductive system of several mammals. It is produced primarily by Sertoli cells (Hagenas et al., 1975; Lipshultz, Murthy \& Tindall, 1982), has a high affinity for $5 \alpha$-dihydrotestosterone (DHT; Lobl, 1981) and differs from sex steroid binding protein which is found in blood serum (Tindall \& Means, 1980; Lobl, 1981).

ABP is normally recovered and characterized from extracts of testes or epididymides but it has been found also in seminal plasma (Jegou, Dacheux \& Terqui, 1978; Jegou \& Le Gac-Jegou, 1978; Plymate, Fariss, Smith, Jacob \& Matej, 1981; Oda, 1982). Its purported function is the transport of androgen to the epididymis (French \& Ritzén, 1973; Danzo, Cooper \& Orgebin-Crist, 1977) where it is taken up by epithelial cells (Tindall \& Means, 1980; Pelliniemi et al., 1981). Proper function of the ductal cells may be dependent on androgen delivered by this mechanism (Hamilton, 1971).

The domestic turkey normally produces white coloured semen, but there is an endemic abnormality known as the yellow semen syndrome which is associated with reduced fecundity. The yellow discoloration is confined to the seminal plasma which also has elevated concentrations of protein, cholesterol and DHT (Thurston, Hess, Biellier, Adldinger \& Solorzano, 1975; Hess \& Thurston, 1982; Hess, Thurston \& Biellier, 1982; Thurston, Hess, Froman \& Biellier, 1982). Other sequelae include abnormal spermatids, numerous macrophages and steatosis of the epithelia of the ductuli efferentes (Thurston et al., 1982). The pathology of yellow semen syndrome, particularly of the epididymal region, could be a manifestation of abnormal metabolism or transport of androgen. The presence of ABP or its binding activity has not been demonstrated in avian semen or

* Present address: Developmental Biology, Northrop Services, Inc., U.S. E.P.A., MD-72, Research Triangle, NC 27711, U.S.A. 
reproductive tissues. We have therefore measured the binding activity for androgens in the seminal plasma of normal turkeys and compared the activity to that in semen from males with yellow semen.

\section{Materials and Methods}

The DHT-binding activity of seminal plasma proteins was determined by disc-gel electrophoresis with tritiated $\left[{ }^{3} \mathrm{H}\right] \mathrm{DHT}$ and steady-state equilibrium conditions (Ritzén, French, Weddington, Nayfeh \& Hansson, 1974). Turkey blood serum was included for comparison of protein bands and binding activity. Rat epididymides served to validate the assay.

Methods. Protein concentrations were determined for all samples using a Coomassie Brilliant Blue G250 assay (Bio-Rad Laboratories) with purified bovine serum albumin as a standard. Each standard curve was analysed by a least squares 'lack of fit' method.

Polyacrylamide gels were prepared according to Davis (1964) and the procedure for electrophoresis was similar to that described by Ritzén et al. (1974). Each gel contained two layers of $6.5 \%$ acrylamide, $0.1 \% \mathrm{~N}, N^{\prime}$-methylene-bis-acrylamide and $10 \%$ glycerol in $0.1 \mathrm{M}-\mathrm{Tris}-\mathrm{HCl}$ buffer (pH 8.9). The bottom layer was $60 \times 5 \mathrm{~mm}$ and contained $2 \mathrm{~nm}-5 \alpha-[1,2,4,5,6,7,16,17-$ $\left.{ }^{3} \mathrm{H}\right]$ dihydrotestosterone; and the top layer was $6 \times 5 \mathrm{~mm}$ and contained $10 \mathrm{~nm}-\left[{ }^{3} \mathrm{H}\right] \mathrm{DHT}$. Both layers were polymerized at the same time. Gels for non-specific binding contained $2 \mathrm{nM}-\left[{ }^{3} \mathrm{H}\right] \mathrm{DHT}$ and $400 \mathrm{nM}$ unlabelled DHT in both layers. Gels for indicating DHT affinity contained no steroid, but the samples were incubated with $4 \mathrm{nM}-\left[{ }^{3} \mathrm{H}\right] \mathrm{DHT}$. The $\left[{ }^{3} \mathrm{H}\right] \mathrm{DHT}$ was added to the gel solutions from a stock preparation containing $5 \mu \mathrm{Ci} / 100 \mu \mathrm{l}$ ethanol. Gels were run for approximately $3 \mathrm{~h}$ at 1 $\mathrm{mA}$ per tube with $4.5 \mathrm{~mm}$-Tris-glycine electrode buffer $(\mathrm{pH} 8.3)$ at $4^{\circ} \mathrm{C}$. After electrophoresis, the gels were cut into $2.4 \mathrm{~mm}$ slices, incubated overnight at room temperature in $5 \mathrm{ml}$ toluene : liquifluor $(24: 1, \mathrm{v} / \mathrm{v}:$ New England Nuclear $)$, and counted for $5 \mathrm{~min}$ or to $2 \%$ accuracy at $58.5 \%$ efficiency. Other gels were stained in Coomassie Brilliant Blue G250 for elucidation of the banding pattern. Calculations were made according to Ritzén et al. (1974) for steady-state binding activity.

Experiment 1. Three groups of 10 males each were selected on the basis of seminal plasma protein concentration and colour (Thurston et al., 1975) from a flock of 500 commercial breeders. Groups were as follows: (1) low protein $(3 \cdot 2-6 \cdot 0 \mathrm{mg} / \mathrm{ml})$ and white colour ; (2) medium protein (6.1$18.2 \mathrm{mg} / \mathrm{ml}$ and white colour; and (3) high protein $(23.0-51.4 \mathrm{mg} / \mathrm{ml})$ and yellow colour. Semen was collected 3 times from all males with a minimum intercollection period of 2 days. The semen was centrifuged at $13000 \mathrm{~g}$ for $5 \mathrm{~min}$ and the supernatant seminal plasma was stored at $-40^{\circ} \mathrm{C}$. For analysis of blood serum, blood was withdrawn from males in Groups 2 and 3 at 2-h intervals before semen collection and the serum was pooled.

Epididymal extracts from 5 adult rats were also analysed. Extracts were obtained by homogenization of tissues in $0.01 \mathrm{M}$-Tris- $\mathrm{HCl}$ buffer $(3: 1$ buffer :tissue; $10 \%$ glycerol; $\mathrm{pH} 7.4)$ at $4^{\circ} \mathrm{C}$ using a polytron (Brinkmann Instruments), then centrifuged at $10000 \mathrm{~g}$ for $15 \mathrm{~min}$. The supernatant was further ultracentrifuged at $100000 \mathrm{~g}$ for $1 \mathrm{~h}$, then stored at $-40^{\circ} \mathrm{C}$ before analysis.

Samples were thawed at $4^{\circ} \mathrm{C}$ and protein concentration was determined. Blood and semen samples were diluted with the Tris- $\mathrm{HCl}$ buffer $(\mathrm{pH} \mathrm{7.4)}$ to a protein concentration of $5 \mathrm{mg} / \mathrm{ml}$. Endogenous steroids were removed from all samples by addition of charcoal (acid-washed, ovendried, Norit A; $1 \mathrm{mg} / \mathrm{mg}$ protein). After $10 \mathrm{~min}$ the charcoal was separated from the supernatant by centrifugation.

The supernatants of all samples were made up to $4 \mathrm{nM}-\left[{ }^{3} \mathrm{H}\right] \mathrm{DHT}, 20 \%$ glycerol and $0.001 \%$ bromophenol blue. Samples for determination of non-specific binding were diluted with buffer containing $800 \mathrm{nM}$ unlabelled DHT, in addition to $8 \mathrm{nM}-\left[{ }^{3} \mathrm{H}\right] \mathrm{DHT}$. Relative affinity for DHT was assessed in semen samples from Groups 2 and 3 by adding the labelled seminal plasma to unlabelled gels. Each electrophoretic gel contained $0.3 \mathrm{mg}$ protein. 
Experiment 2. Semen was collected once from 5 males with white semen and 8 with yellow semen and the plasma was stored at $-40^{\circ} \mathrm{C}$. Individual samples were evaluated for $\mathrm{ABP}$ activity as for Exp. 1 .

Statistical analysis. The results of Exps 1 and 2 were analysed separately because of the differences in sampling, i.e. pooled versus individual. Group variances for binding activity were not homogeneous amongst protein groups (computed as the ratio of their variances); therefore, multiple comparisons among means (Exp. 1) were made after $\log _{\mathrm{e}}$ transformation. Comparisons between two means (Exp. 2) were made by the Student's $t$ distribution with different variances (Ott, 1977).

\section{Results}

DHT binding activity was found in pooled and individual turkey seminal plasma, having an electrophoretic mobility $\left(R_{\mathrm{f}}\right)$ value of approximately $0.3,0.5$ or 0.8 (Text-figs $1 \mathrm{a} \mathrm{\&} 1 \mathrm{c}$ ). Activity at $R_{\mathrm{f}}=0.3$ or 0.8 was more frequently detected in normal white seminal plasma, whereas yellow seminal plasma binding activity was especially pronounced at $R_{\mathrm{f}}=0.5$. The increased binding activity at $R_{\mathrm{f}} 0.5$ in yellow semen corresponded to a particular band as determined by Coomassie Blue stain (Text-fig. 1c), but was less discernible in white semen (Text-fig. 1a). Significant radioactivity was detected at the beginning of the gels in all samples $\left(R_{\mathrm{f}}=0 \cdot 17\right)$, but was usually more prominent in samples with the least DHT-binding activity. Therefore, this was presumed to be residual radioactivity from the $10 \mathrm{nM}-\left[{ }^{3} \mathrm{H}\right] \mathrm{DHT}$ in the top layer of the gels.

Activity was particularly high in yellow seminal plasma (Tables $1 \& 2$ ), and the increase in specific activity as seminal plasma protein concentration increased was disproportionate. This indicates that the protein responsible for binding at $R_{\mathrm{f}}=0.5$ may have increased in concentration at a greater rate than for other plasma proteins in yellow semen. Binding activities for the pooled samples are reported as geometric means (Table 1). Individual yellow seminal plasma samples had a large variation in activity (Table 2 ), but, as for the pooled samples, bound more $\left[{ }^{3} \mathrm{H}\right] \mathrm{DHT}$ than did seminal plasma from normal males.

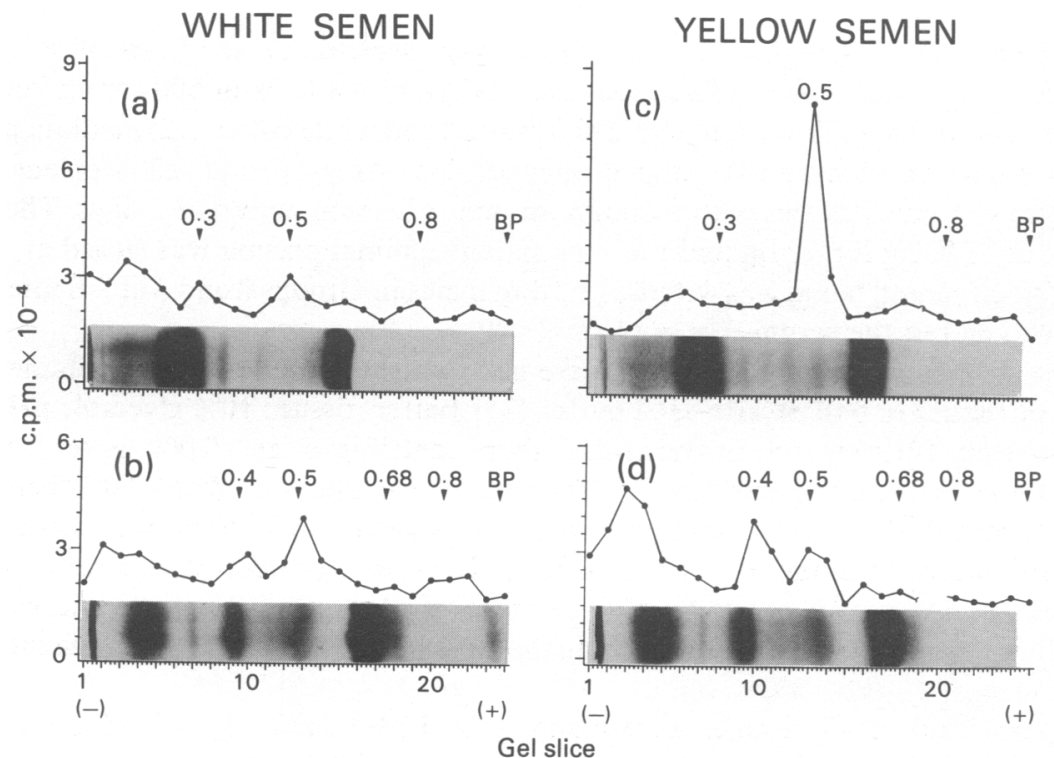

Text-fig. 1. Steady-state polyacrylamide gel electrophoresis of seminal plasma (a,c) and blood serum (b, d) from turkeys with white $(a, b)$ or yellow (c, d) semen (Exp. 2). Stained gels under each plot are aligned according to protein migration, from cathode $(-)$ to anode $(+)$. BP = bromophenol blue front. $R_{\mathrm{f}}$ values are indicated above the plots. 
Table 1. Protein concentration and androgen-binding activity in turkey seminal plasma (Exp. 1)

\begin{tabular}{cccccc}
\hline & & & & \multicolumn{2}{c}{ Binding activity* } \\
\cline { 5 - 6 } Group & $\begin{array}{l}\text { Semen } \\
\text { colour }\end{array}$ & $\begin{array}{c}\text { No. of } \\
\text { reps }\end{array}$ & $\begin{array}{c}\text { Protein* } \\
(\mathrm{mg} / \mathrm{ml})\end{array}$ & pmol DHT/ml & pmol DHT/mg protein \\
\hline 1 & White & 3 & $6 \cdot 81 \pm 0 \cdot 04^{\mathrm{a}}$ & $0.413 \pm 0 \cdot 106^{\mathrm{a}}$ & $0 \cdot 076 \pm 0.030^{\mathrm{a}}$ \\
2 & White & 3 & $11 \cdot 15 \pm 0 \cdot 04^{\mathrm{b}}$ & $1.408 \pm 0 \cdot 106^{\mathrm{a}}$ & $0 \cdot 150 \pm 0.030^{\mathrm{b}}$ \\
3 & Yellow & 3 & $41 \cdot 45 \pm 0 \cdot 04^{\mathrm{c}}$ & $22 \cdot 155 \pm 0 \cdot 106^{\mathrm{b}}$ & $0.607 \pm 0.030^{\mathrm{c}}$ \\
\hline
\end{tabular}

* Pooled seminal plasma from 10 males.

* Geometric means \pm s.e. Different superscripts within a column indicate a significant difference $(P \leq 0 \cdot 05)$.

Table 2. Protein concentration and androgen-binding activity in turkey seminal plasma (Exp. 2)

\begin{tabular}{|c|c|c|c|c|}
\hline \multirow{2}{*}{$\begin{array}{l}\text { Semen } \\
\text { colour }\end{array}$} & \multirow{2}{*}{$\begin{array}{c}\text { No. of } \\
\text { samples }\end{array}$} & \multirow{2}{*}{$\begin{array}{l}\text { Protein* } \\
(\mathrm{mg} / \mathrm{ml})\end{array}$} & \multicolumn{2}{|c|}{ Binding activity* } \\
\hline & & & $\mathrm{pmol} \mathrm{DHT/ml}$ & $\mathrm{pmol} \mathrm{DHT} / \mathrm{mg}$ protein \\
\hline White & 5 & $9.5 \pm 0.36^{a}$ & $1.45 \pm 0.30^{\mathrm{a}}$ & $0.153 \pm 0.030^{2}$ \\
\hline Yellow & 8 & $35.85 \pm 4.04^{b}$ & $32.50 \pm 7.93^{\mathrm{b}}$ & $0.850 \pm 0.115^{b}$ \\
\hline
\end{tabular}

* Means \pm s.e. Different superscripts indicate a significant difference $(P \leq 0 \cdot 05)$.
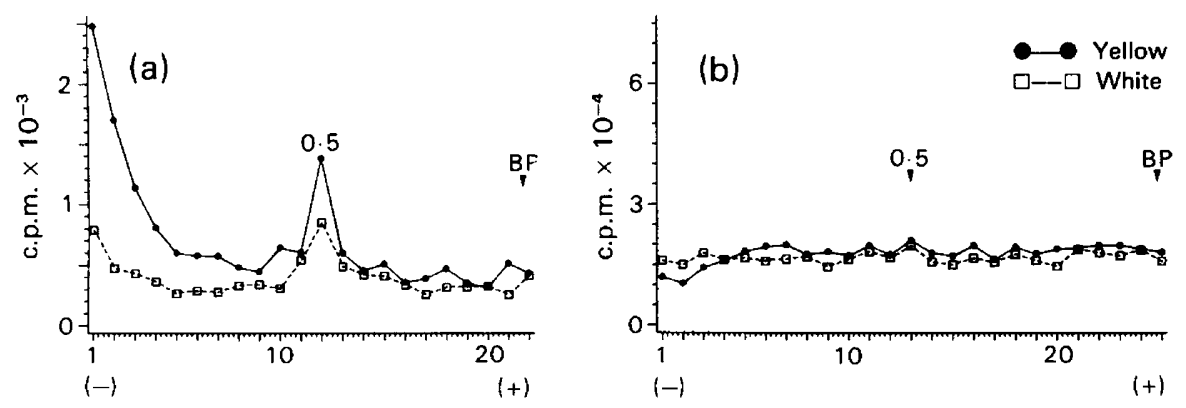

Gel slice

Text-fig. 2. Radioactivity in gel slices from tritiated samples of white and yellow seminal plasma which was electrophoresed on an unlabelled gel (a). (b) Non-specific binding as determined by steady-state polyacrylamide gel electrophoresis with gels containing excess unlabelled DHT (400 nM) in addition to $2 \mathrm{nM}-\left[{ }^{3} \mathrm{H}\right] \mathrm{DHT}$. BP $=$ bromophenol blue front. The $R_{\mathrm{f}}$ value of 0.5 is indicated.

Seminal plasma from birds with white and yellow semen incubated with $\left[{ }^{3} \mathrm{H}\right] \mathrm{DHT}$ but electrophoresed with gels containing no steroid, still showed binding activity with an $R_{\mathrm{f}}=0 \cdot 5$ (Text-fig. 2a). Non-specific binding was insignificant as determined by gels containing 2 nM$\left[{ }^{3} \mathrm{H}\right] \mathrm{DHT}$ and an excess of unlabelled DHT (Text-fig. 2b).

DHT-binding activity was found in at least three peaks in blood serum samples from a normal male with white semen; $R_{\mathrm{f}}$ values were about $0.4,0.5$ and 0.8 (Text-fig. $1 \mathrm{~b}$ ). Serum from a male with yellow semen showed more binding at 0.4 than at 0.5 and no activity at 0.8 (Text-fig. $1 \mathrm{~d}$ ). Blood serum and seminal plasma albumin had little binding activity and migrated with an $R_{\mathrm{f}}$ of approximately 0.68 and 0.64 , respectively (Text-figs $1 \mathrm{a}-\mathrm{d}$ ).

Rat epididymis contained a distinct binding activity $(977.3 \pm 115.9 \mathrm{fmol} \mathrm{DHT} / \mathrm{mg}$ protein) with an $R_{\mathrm{f}}$ of $0 \cdot 39$, similar to that found by others (Tindall et al., 1975; Lipshultz et al., 1982). 


\section{Discussion}

The seminal plasma DHT-binding activity at an approximate $R_{\mathrm{f}}$ of 0.5 was more than 20 times higher in yellow turkey semen than in normal white semen, and may represent a specific seminal plasma androgen-binding protein. The association of reproductive problems with an increase in ABP activity has not been reported (Lobl, 1981); however, a decreased activity of ABP has been associated with genetic reproductive failure in male rats (Musto \& Bardin, 1976). Due to insufficient semen volume, the relative binding affinity and specificity were not determined for the DHT-binding in the present study.

ABP with an $R_{\mathrm{f}}$ of 0.5 has been detected in mammalian semen (Jegou et al., 1978) and in testicular and epididymal extracts (Sanborn, Elkington, Tcholakian \& Steinberger, 1975; Jegou et al., 1978; Carreau, Drosdowsky \& Courot, 1979; Feldman et al., 1981). In other reports, seminal ABP was found to migrate near $R_{\mathrm{f}}=0.3$ (Jegou \& Le Gac-Jegou, 1978; Barahona, Banuelos, Solis \& Bermudez, 1980; Plymate et al., 1981), which is similar to one peak of activity in the white turkey seminal plasma. Since yellow semen contained much more activity at $R_{\mathrm{f}} 0 \cdot 5$, the protein responsible may have removed the $\left[{ }^{3} \mathrm{H}\right] \mathrm{DHT}$ from the slower moving peaks, indicating that binding at $R_{\mathrm{f}} 0.3$ or 0.8 was of low affinity.

Other possible explanations of DHT-binding in turkey semen include blood plasma steroidbinding proteins and cytoplasmic androgen receptors. Corticosterone binding globulin (CBG), an $\alpha$-globulin (Daughaday, 1959), migrates with an $R_{\mathrm{f}}$ near 0.5 and binds testosterone in addition to cortisol and progesterone (Corvol, Chrambach, Rodbard \& Bardin, 1971; Martin \& Ozon, 1975; Wagner, 1978; Barahona et al., 1980). However, the seminal plasma binding activity is probably not due to CBG, because $\left[{ }^{3} \mathrm{H}\right] \mathrm{DHT}$ peaks do not appear in PAGE or agar electrophoresis of human blood plasma (Wagner, 1978; Barahona et al., 1980).

Sex steroid-binding protein (SBP), in contrast, binds DHT and testosterone with high affinity (Wagner, 1978). SBP is a $\beta$-globulin, and SBP from several mammals migrates with an $R_{\mathrm{f}}$ of about $0 \cdot 3$ (Corvol et al., 1971; Purvis, Calandra, Sander \& Hansson, 1978; Barahona et al., 1980). However, SBP has not been detected in adult avian blood (Corvol \& Bardin, 1973; Salhanick \& Callard, 1979), although it has been demonstrated in turtles, fish and amphibians (Salhanick \& Callard, 1979).

The present study suggests that steroid-binding proteins of undetermined specificity exist in turkey blood with peaks of activity at $R_{\mathrm{f}}=0.4$ and 0.5 . The activity at $R_{\mathrm{f}}=0.5$ was decreased in blood from a male with yellow semen while that at $R_{\mathrm{f}}=0.4$ was increased. It is therefore possible that the increased activity at $R_{\mathrm{f}}=0.5$ in yellow semen may be due to influx of a blood plasma DHTbinding protein. Tindall, Cunningham \& Means (1978) suggested that SBP may be transported from blood into the reproductive tract because, in the rabbit, SBP decreased and ABP increased in concentration with age.

The elevated levels of protein in yellow semen appear to originate from excessive apocrine secretion and cytoplasmic extrusion by non-ciliated cells of the ductuli efferentes (Hess $\&$ Thurston, 1977; Hess et al., 1982). With cellular damage or excessive blebbing, androgen receptors from the cytoplasm may be released into the ductal lumen. However, cytoplasmic receptors are not thought to be responsible for the increased DHT-binding activity in yellow semen. The dissociation of DHT from cytosol receptors requires days rather than minutes (Tindall \& Means, 1980). In the present study, the amount of $\left[{ }^{3} \mathrm{H}\right] \mathrm{DHT}$ bound to turkey seminal plasma ABP was greatly reduced after electrophoresis for $3 \mathrm{~h}$ in unlabelled gels.

It is possible that the binding protein is synthesized by epithelial cells of the epididymal region and that, in the yellow semen syndrome, the extrusion of excessive amounts of cytoplasm includes a DHT-binding protein. Alternatively, a high-affinity ABP may serve as a reservoir that binds excess androgen in the ductal lumen. Males with the yellow semen syndrome have high levels of seminal plasma DHT (Hess, 1983). The increased binding activity concomitant with an increase in an ABP may be consequential to elevated DHT. 
Published with approval of the Director of the South Carolina Agricultural Experiment Station as Technical Contribution No. 2188.

\section{References}

Barahona, E., Banuelos, J., Solis, J. \& Bermudez, J.A. (1980) Preliminary characterization of a new androgen-binding protein in human seminal plasma. Archs Androl. 4, 235-248.

Carreau, S., Drosdowsky, M.A. \& Courot, M. (1979) Age related effects on androgen binding protein in sheep testis and epididymis. Int. J. Androl. 2, 49-61.

Corvol, P. \& Bardin, C.W. (1973) Species distribution of testosterone-binding globulin. Biol. Reprod. 8, 277282.

Corvol, P.L., Chrambach, A., Rodbard, D. \& Bardin, C.W. (1971) Physical properties and binding capacity of testosterone-estradiol-binding globulin in human plasma, determined by polyacrylamide gel electrophoresis. J. biol. Chem. 246, 3435-3443.

Danzo, B.J., Cooper T.G. \& Orgebin-Crist, M.-C. (1977) Androgen binding protein in fluids collected from the rete testis and cauda epididymis of sexually mature and immature rabbits and observations on morphological changes in the epididymis following ligation of the ductuli efferentes. Biol. Reprod. 17, 64-67.

Daughaday, W.H. (1959) Steroid protein interaction. Physiol. Rev. 39, 885-902.

Davis, B.J. (1964) Disc electrophoresis. II. Method and application to human serum proteins. Ann. N.Y. Acad. Sci. 121, 404-427.

Feldman, M., Lea, O.A., Putrusz, P., Tres, L.L., Kierszenbaum, A.L. \& French, F.S. (1981) Androgenbinding protein. Purification from rat epididymis, characterization, and immunochemical localization. J. biol. Chem. 256, 5170-5175.

French, F.S. \& Ritzén, E.M. (1973) A high-affinity androgen-binding protein (ABP) in rat testis: evidence for secretion into efferent duct fluid and absorption by epididymis. Endocrinology 93, 88-95.

Hagenas, L., Ritzén, E.M., Plöen, L., Hansson, V., French, F.S. \& Nayfeh, S.N. (1975) Sertoli cell origin of testicular androgen-binding protein (ABP). Molec. cell. Endocr. 2, 339-350.

Hamilton, D.W. (1971) Steroid function in the mammalian epididymis. J. Reprod. Fert., Suppl. 13, 88-97.

Hess, R.A. (1983) Biochemical and endocrine parameters of reproduction in the male turkey. Ph.D. dissertation, Clemson University.

Hess, R.A. \& Thurston, R.J. (1977) Ultrastructure of the epithelial cells in the epididymal region of the turkey (Meleagris gallopavo). J. Anat. 124, 765-778.

Hess, R.A. \& Thurston, R.J. (1982) Incidence and biochemistry of yellow turkey semen. Poultry Sci. 61, 1381.

Hess, R.A., Thurston, R.J. \& Biellier, H.V. (1982) Morphology of the epididymal region of turkeys producing abnormal yellow semen. Poultry Sci. 61, $531-539$.

Jegou, B. \& Le Gac-Jegou, F. (1978) Androgen binding protein in the seminal plasma of some mammalian species. J. Endocr. 77, 267-268.

Jegou, B., Dacheux, J.-L. \& Terqui, M. (1978) Demon- stration of an androgen binding protein in the seminal plasma of the ram. C. r. hebd. Séanc. Acad. Sci., Paris D 286, 347-350.

Lipshultz, L.I., Murthy, L. \& Tindall, D.J. (1982) Characterization of human Sertoli cells in vitro. $J$. clin. Endocr. Metab. 55, 228-237.

Lobl, T.J. (1981) Androgen transport proteins: physical properties, hormonal regulation, and possible mechanism of TeBG and ABP action. Archs Androl. 7, 133151.

Martin, B. \& Ozon, R. (1975) Steroid-protein interactions in non-mammalian vertebrates. II. Steroid binding proteins in the serum of amphibians; a physiological approach. Biol. Reprod. 13, 371-380.

Musto, N.A. \& Bardin, C.W. (1976) Decreased levels of androgen binding protein in the reproductive tract of the restricted (Hre) rat. Steroids 28, 1-11.

Oda, T. (1982) Source of androgen binding protein in human seminal plasma. Acta obstet. gynaec. jap. 34, 137-143.

Ott, L. (1977) An Introduction to Statistical Methods and Data Analysis. Wadsworth Publishing Company, Inc., Belmont.

Pelliniemi, L.J., Dym, M., Gunsalus, G.L., Musto, N.A., Bardin, C.W. \& Fawcett, D.W. (1981) Immunocytochemical localization of androgen-binding protein in the male rat reproductive tract. Endocrinology 108, 925-931.

Plymate, S.R., Fariss, B.L., Smith, M.L., Jacob, W.H. \& Matej, L.A. (1981) Seminal fluid androgen binding protein. Andrologia 13, 308-313.

Purvis, K., Calandra, R., Sander, S. \& Hansson, V. (1978) Androgen binding proteins and androgen levels in the human testis and epididymis. Int. J. Androl. 1, 531-548.

Ritzén, E.M., French, F.S., Weddington, S.C., Nayfeh, S.N. \& Hansson, V. (1974) Steroid binding in polyacrylamide gels. Quantitation at steady state conditions. J. biol. Chem. 249, 6597-6604.

Salhanick, A.C.R. \& Callard, I.P. (1979) Sex steroid binding protein in non-mammalian vertebrates. In Steroid Hormone Receptor Systems, pp. 441-459. Eds W. W. Leavitt \& J. H. Clark. Plenum Press, New York.

Sanborn, B.M., Elkington, J.S.H., Tcholakian, R.K. \& Steinberger, E. (1975) Some properties of androgenbinding activity in rat testis. Molec. cell. Endocr. 3, 129-142.

Thurston, R.J., Hess, R.A., Biellier, H.V., Adldinger, H.K. \& Solorzano, R.F. (1975) Ultrastructural studies of semen abnormalities and Herpesvirus associated with cultured testicular cells from domestic turkeys. J. Reprod. Fert. 45, 235-241.

Thurston, R.J., Hess, R.A., Froman, D.P. \& Biellier, H.V. (1982) Elevated seminal plasma protein: a characteristic of yellow turkey semen. Poultry Sci. 61, 19051911.

Tindall, D.J. \& Means, A.R. (1980) Properties and 
hormonal regulation of androgen binding proteins. In Advances in Sex Hormone Research, vol. IV, pp. 295327. Eds J. A. Thomas \& R. L. Singhal. Urban and Schwarzenberg, Baltimore.

Tindall, D.J., Hansson, V., McLean, W.S., Ritzén, E.M., Nayfeh, S.N. \& French, F.S. (1975) Androgenbinding proteins in rat epididymis: properties of a cytoplasmic receptor for androgen similar to the androgen receptor in ventral prostate and different from androgen-binding protein (ABP). Molec. cell. Endocr. 3, 83-101.
Tindall, D.J., Cunningham, G.R. \& Means, A.R. (1978) Structural requirements for steroid binding to androgen binding proteins. Int. J. Androl., Suppl. 2, 434 448.

Wagner, R.K. (1978) Extracellular and intracellular steroid binding protein. Properties, discrimination, assay, and clinical application. Acta endocr., Copenh., Suppl. 218, 1-73.

Received 5 September 1983 